\title{
Isolation and Purification of 18KD Protein of Sika Deer Antler Plate and its Antibacterial Activity
}

\author{
Lin Qi, Lu Li, Danyang Chen, Mingxiao Liu, Yan Wu and Wei Hu* \\ College of Life Science, Jilin Agriculture University, Changchun 130118, Jilin Province, China
}

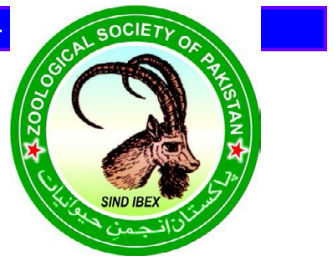

\begin{abstract}
A B S T R A C T
We isolated a novel monomeric peptide from antler plate polypeptide (APP-1) of sika deer which inhibited the growth of both Gram-positive and Gram-negative bacteria. The molecular mass and purity of this polypeptide was determined by ultra-performance liquid chromatography (UPLC) and Bruker micOTOF OllQ TOF mass spectrometry, respectively. The full amino-acid sequence of the monomericpeptide was analyzed by sequential Edman degradation using a protein/peptide sequencer. The antibacterial activity of the protein monomer in antlerplate was studied by disc diffusion method, and the antibacterial ring diameter of each antibacterial agent was measured to determine its antibacterial ability. The molecular mass and purity of this polypeptide was $18.970 \mathrm{kDa}$ and $90 \%$. Amino acid sequence analyses indicated that the $\mathrm{N}$-terminal amino-acid sequence of this monomeric peptide was AAQSLLACGAARLYKIIQQWPHYRR. The results showed that under the effect of various bacteriostatic agents, Enterobacter aeruginosa, Bacillus subtilis, Escherichia coli, Pseudomonas aeruginosa, Staphylococcus intermedius, Xylose staphylococcus all showed different degree of inhibitory effect. The inhibitory effect of the protein monomer on grampositive bacteria was stronger than that on gram-negative bacteria, but not on candida albicans. This novel and monomeric APP-1 has antibacterial activities and imply that it is likely an important component of antibacterial activity in antler plate polypeptide.
\end{abstract}

\begin{tabular}{l} 
Article Information \\
Received 16 February 2019 \\
Revised 19 June 2019 \\
Accepted 11 July 2019 \\
Available online 01 October 2019 \\
Authors' Contribution \\
\hline WH conceived the study. LQ \\
performed the experiments and wrote \\
the manuscript. LL and ML helped \\
in data analysis and manuscript \\
preparation. DC and YW helped in \\
experimental work. \\
Key words \\
\hline Sika, antler plate, Monomer \\
polypeptide, Antibacterial activities
\end{tabular}

\section{INTRODUCTION}

The antler plate is the ossified disc material left on the horn stalk of the male sika deer after sawing antler, and it will fall off automatically before the new antler grows in the following spring. Deer antlerplate has obvious effect on the treatment of mammary gland hyperplasia, breast swelling and mastitis, as well as the effects of bacteriostasis, anti-fatigue, analgesia, anti-inflammatory, hypoglycemic and antioxidant. It has a good prospect of development and utilization. Protein and polypeptide play an important role in life activities. The total protein content of the antler plate is up to $40 \%$, which is one of the main functional components. Compared to the larger molecular weight proteins, small molecule protein is more likely to be absorbed by the body, which has more obvious health care effect. Research of the protein monomer able to establish a good connection between protein engineering research and genetic engineering research and make contributions to the development of proteomics. Therefore, in recent years,

\footnotetext{
* Corresponding author: huweilab@126.com 0030-9923/2020/0001-0007 \$9.00/0

Copyright 2020 Zoological Society of Pakistan
}

more and more researchers focused on the small molecular protein monomer and peptide monomer in research of sika deer antler plate.

Huang et al. (2010) obtained the peptide monomer of sika deer antler plate whose relative molecular mass size is $7.1276 \mathrm{kDa}$ by $\mathrm{pH} 3.5$ dilute acetic acid buffer homogenate extraction, chromatographic resource $\mathrm{S}$ column purification, Superdex 75 gel column chromatography, and the reversed phase high performance liquid, then delivered it into KK-ay mice to observe the hypoglycemic activity and structured insulin resistance model for investigating the effects of peptides on insulin resistance HepG2 cell sugar consumption. The results showed that this peptide can reduce the KK-ay mice blood sugar levels and can significantly improve sugar consumption of insulin resistance model, which indicated that the protein monomer has certain hypoglycemic activity. Wang et al. (2008) obtained the CPP of sika deer antler plate protein through enzymatic hydrolysis, and its relative molecular weight was detected by electrophoresis SDS-PAGE with a range of $8-15 \mathrm{kDa}$. The activity test proved that CPP could resist hyperplasia of rat mammary gland and significantly affect the phagocytic function of mice. Qiu et al. (2007) used $45^{\circ} \mathrm{C}$ distilled water to extract antler plate after crushing it into a powder particle of $0.01 \mathrm{~mm}$, and suctioned filtration 
the extracting solution, then got protein precipitate by salting-out, renatured the protein precipitation and obtained anlter plate protein APPB by methods of dialysis and chromatography. To detect the relative molecular mass of it was detected by electrophoresis with the range of 20.1$31.0 \mathrm{kDa}$, and the results of acetic acid-induced writhing reaction in mice showed that it has analgesic action. Li et al. (2011) used petroleum ether, ethyl ether, methanol and $80 \%$ methanol to extract the plum-spotted deer antler plate, and then carried out column chromatography on the extract to obtain a polypeptide monomer with a relative molecular weight of 691.104Da. The study on its activity found that the monomer had anti-fatigue effect and antibacterial effect.

The bacteriostatic activity of anlter plate and its protein has also been rarely reported. Xiao (2012) grinded sika deer antler plate into powder, then made of $1 \%$ water suspension $(10 \mathrm{mu} \mathrm{g} / \mathrm{mL})$, used penicillin and streptomycin as positive control and Staphylococcus aureus and Escherichia coli as test organisms to carries on the in vitro bacteriostatic ring test. The results showed that the inhibition to s. aureus from strong to weak in correct order is: penicillin $>$ plum antler plate liquid $>$ streptomycin. The inhibitory ability to Escherichia coli was successively from strong to weak: streptomycin $>$ plum antler plate liquid $>$ penicillin. Huang et al. (2011) studied the antibacterial effect of sika deer antler plate extract on hemolytic streptococcus and Escherichia coli through the paper inhibition method, and the results showed that sika deer antler plate protein extracts had obvious antibacterial effect. However, the larger the molecular weight of the protein, it would be more difficult to be absorbed by the body. Therefore, this project takes the small molecule protein polypeptide as the entry point to search and find the small molecule protein with bacteriostatic activity from the antler plate and study its activity, which is of great significance for the in-depth research and development of this precious animal medicine.

\section{MATERIALS AND METHODS}

\section{Extraction of total protein from antler plate}

The $400 \mathrm{~g}$ antler powder was add into $2000 \mathrm{ml}$ acetic acid-sodium acetate buffer of $\mathrm{pH} 3.6$ which is fully precooling in $4^{\circ} \mathrm{C}$ refrigerator, the homogenization was centrifuged and supernatant was extracted. The fully precooling 95\% ethanol was slowly added into the supernatant until the final concentration of $55 \%$, then the supernatant was placed in $4^{\circ} \mathrm{C}$, after $4 \mathrm{~h}$ it was centrifuged $\left(4^{\circ} \mathrm{C}, 6000 \mathrm{RPM}, 20 \mathrm{~min}\right)$ and the supernatant was extracted. Supernatant fluid was rotary evaporated to concentrate volume of $100 \mathrm{ml}$ under the condition of $40^{\circ} \mathrm{C}$, and it was freeze-dried. Finally, the crude extracts of antler plate were obtained.

\section{Desalination of crude extracts of total protein}

Gel filtration chromatography (G25) was used. The outlet of the column was sealed, and a quarter of the column volume of deionized water was poured into the bottom of the column, and then the gel homogenate was slowly poured into the column. After the gel settlement of about $1-2 \mathrm{~cm}$ appeared at the bottom of the column, the outlet of the column was opened, and the flow rate was controlled at $1 \mathrm{~mL} / \mathrm{min}$ by the peristaltic pump. The gel homogenate was gradually pour into the column for supplementing the outflow of deionized water until the gel settlement was about $2 \mathrm{~cm}$ above the mark. Deionized water was the mobile phase and the column was balanced for $12 \mathrm{~h}$. The sample solution was slowly dribbled into the column and eluted with deionized water. The light absorption value was detected by the nucleic acid protein detector at 280 $\mathrm{nm}$, and the collection began after the peak. The collection stopped when the light absorption value returned to the baseline, and it was continued to be eluted with deionized water. After the elution, the outlet was shut down.

Separation of protein monomer antlerplate by reversedphase high performance liquid chromatography (analytical RP-HPLC)

The instrumentswere shimazu analytical HPLC, ultraviolet spectrophotometric detector and binary gradient pump. ACE analytical reversed phase HPLC column (ACE-221-2546), ACE 5 c18-300 4.6 250mm analytical column. $100 \mathrm{mg}$ desalted total peptide from antler plate was dissolved in $2 \mathrm{~mL} 15 \%$ acetonitrile solution through a 0.22 $\mathrm{m}$ microporous filter. The mobile phase was divided into A phase and B phase. Phase A was $1 \mathrm{~mL}$ chromatographically pure trifluoroacetic acid (TFA) $+1000 \mathrm{~mL}$ degasified ultrapure water, and phase B was $0.85 \mathrm{ml}$ chromatographically pure trifluoroacetic acid (TFA) $+1000 \mathrm{~mL}$ degasified acetonitrile. The elution gradient was set as $0 \%$ acetonitrile concentration and $0-5 \mathrm{~min} .0 \%-0 \%, 5-35 \mathrm{~min} ; 70 \%-70 \%$, 35 to $50 \mathrm{~min}$. The injection volume was $80 \mathrm{~L}(50 \mathrm{mg} / \mathrm{ml})$ per gradient. The detection wavelength was $215 \mathrm{~nm}$. The column temperature was $22^{\circ} \mathrm{C}$ and the velocity was $1 \mathrm{ml} /$ min. At the end of each gradient, the $20 \%$ acetonitrile balanced chromatographic column was used for $40 \mathrm{~min}$, and the flow rate was still $1.0 \mathrm{~mL} / \mathrm{min}$, and the peaks were collected. The collected peaks were analyzed by electrospray mass spectrometry with the assistance of Chang Chun Institute of Applied Chemistry, Chinese Academy of Sciences. The mass spectrometer is Thermo, LTQ XL electrospray mass spectrometer. 
Enrichment of target small molecule protein monomer

After the detection of each peak electrospray mass spectrometry in reverse high-performance liquid phase, it was found that the peak at $28.93 \mathrm{~min}$ of liquid phase was a single small molecule protein with high purity and content, so the peak at $28.93 \mathrm{~min}$ was taken as the target for enrichment. According to the calculation, when the concentration of B phase liquid is about $55.9 \%$, the target summit appears. The instrument used for enrichment was the Swedish AKTA purifier $215 \mathrm{~nm}$ protein purification system (model AKTA purifier 100), ultraviolet spectrophotometric detector and binary gradient pump. The chromatographic column was the semi-prepared reversed phase column (Zorbax 300SB $\mathrm{C}_{18}$ ). The norm of the column is Zorbax $300 \mathrm{SB} \mathrm{C}_{18} 9.4 \times 250 \mathrm{~mm}$ prepared column. The total peptide desalting solution of antler plate was $200 \mathrm{mg}$ and it was dissolved in $2 \mathrm{~mL} 15 \%$ acetonitrile solution through a $0.45 \mathrm{~m}$ microporous filter. The mobile phase was divided into A phase and B phase. Phase A was $1 \mathrm{~mL}$ chromatographically pure trifluoroacetic acid (TFA) $+1000 \mathrm{~mL}$ degasified ultra-pure water, and phase B was $0.85 \mathrm{ml}$ chromatographically pure trifluoroacetic acid (TFA) $+1000 \mathrm{~mL}$ degasified acetonitrile. The elution gradient was set as $0 \%$ acetonitrile concentration and $0-5 \mathrm{~min} .0 \%-0 \%, 5-35 \mathrm{~min} ; 70 \%-70 \%, 35$ to $50 \mathrm{~min}$. The injection volume was $500 \mathrm{~L}$ per gradient. The detection wavelength was $215 \mathrm{~nm}$. The column temperature was $40^{\circ} \mathrm{C}$; the flow rate was $1.8 \mathrm{ml} / \mathrm{min}$. At the end of each gradient, the column was balanced with $20 \%$ acetonitrile for $40 \mathrm{~min}$, and the flow rate was still $1.8 \mathrm{~mL} / \mathrm{min}$. The target peak was collected, and each collection was merged and conserved in fluid $-20^{\circ} \mathrm{C}$.

\section{HPLC detection of target protein}

The instruments used was shimazu analytical HPLC (lc-10atvp), ultraviolet spectrophotometric detector and binary gradient pump. The column size is ACE 5 c18-300 $4.6250 \mathrm{~mm}$ analytical column. The elution gradient was set as $0 \%$ acetonitrile concentration and $0-5 \mathrm{~min} .0 \%-0 \%$, 5-15 min; $10 \%-60 \%$ and $15-45 \mathrm{~min} .45-60 \%-60 \%, 50$ min. The injection volume was $20 \mathrm{~L}$, other conditions were the same as 1.3. When the concentration of liquid B was about $55.9 \%$, the target summit would appear, and the corresponding time should be about 40min.

\section{Mass spectrometry of the target protein (Mascot)}

This part is accomplished with the assist of institute of Basic Medicine, Chinese Academy of Medical Sciences. Mascot is the protein retrieval and identification software, and the database is NCBI. The enzyme used for enzymatic hydrolysis of the target protein enrichment solution is trypsin. After enzymatic hydrolysis, MS/MS secondary mass spectrometry was used to identify the enzymatic hydrolysis fragments. The results were compared with the NCBI protein database using Mascot software, and the matching proteins were found and analyzed. The specific query conditions were shown in Table 1 .

\section{Table I. Query conditions.}

\begin{tabular}{ll}
\hline Kinds & Conditions \\
\hline Enzyme used in the experiment & Trypsin \\
Missed enzyme cleavage site & 1 \\
Fixed modification & Carbamidomethyl (C) \\
Variable modification & Oxidation(M) \\
The mass error range of the & $50 \mathrm{ppm}$ \\
first mass spectrometry & \\
$\begin{array}{l}\text { The mass error range of the } \\
\text { second mass spectrometry }\end{array}$ & $0.5 \mathrm{Da}$ \\
\hline
\end{tabular}

Preliminary study on bacteriostatic activity of target protein

The antibacterial activity of total protein and protein monomer in antlerplate was studied by disc diffusion method, and the antibacterial ring diameter of each antibacterial agent was measured to determine its antibacterial ability. The gram-negative bacterium included Enterobacter aerogenes, Proteus, Pseudomonas and E. coli. The gram-positive bacterium included, Staphylococcus aureus, Lactococcus lactis, Xylose staphylococcus, Bacillus subtilis and Staphylococcus intermedius. The fungus was Candida albicans. The grampositive bacteria and gram-negative bacteria colonies were picked respectively from the slant medium to subculture $\left(37^{\circ} \mathrm{C}\right.$ constant temperature oscillation culture) until the logarithmic phase, the cultivated bacteria solution would be diluted to $105-106 \mathrm{cfu} / \mathrm{mL}$. The diluent was used as bacteria solution for the test. Then the Candida albicans colonies were picked from slant medium to subculture $\left(30^{\circ} \mathrm{C}\right.$ constant temperature oscillation cultivate) until the logarithmic phase. The cultivated bacteria solution will be diluted to $105-106 \mathrm{cfu} / \mathrm{mL}$. The diluent was used as bacteria solution for the test.

Next, the inhibition experiment ring was performed. Lyophilized dried products of total protein and small protein monomer of antler plate were $1 \mathrm{mg}$ each, and were fully dissolved with $0.1 \mathrm{ml}$ deionized water. Six petri dishes were taken and labeled as the positive control group, the negative control group (the negative control group was deionized water), the total protein group and the small molecule protein monomer group, and several circular filter sheets were put into each group. According to the grouping, corresponding bacteriostatic agent which is 
average $10 \mathrm{uL}$ was taken to infiltrate into the corresponding filter sheet, each filter sheet was patched after dried. After the solid medium was fully solidificated and temperature of it was closed to room temperature, $200 \mathrm{uL}$ activated microbial was evenly coated in the solid medium, then the filter sheet was patched. Finally, the medium was inverted cultured. Candida albicans should be inverted cultured in $30^{\circ} \mathrm{C}$ incubator for $18-20 \mathrm{~h}$, the rest of the gram negative bacteria and gram positive bacteria were inverted in $37^{\circ} \mathrm{C}$ incubator 16-18 h. After inverted culture, the diameter of each bacteriostatic ring was measured with vernier caliper.

\section{RESULTS}

\section{SDS-PAGE electrophoresis analysis of total peptide in antler plate}

After desalting by Sephadex g-25 gel chromatography, the crude extract of total peptides from antler plate was white flocculent and easily soluble in water. Figure 1 showed the electrophoresis results of total peptide of antler plate. It could be found from the figure that after alcohol precipitation and desalination, the protein of antler plate was mainly concentrated below $29.0 \mathrm{kDa}$, and a band around $20.1 \mathrm{kDa}$ was obvious.

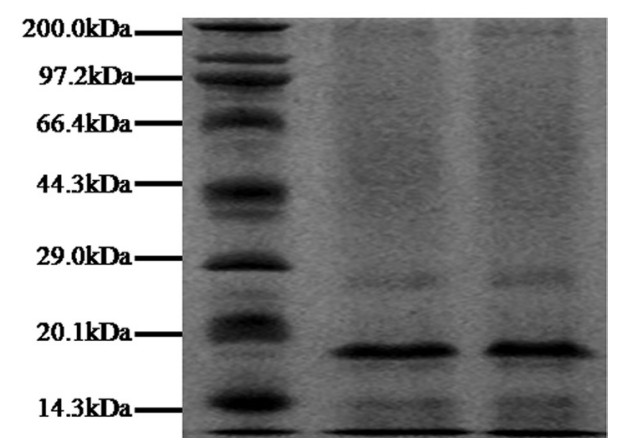

Fig. 1. SDS-PAGE electrophoresis results of total peptides from antler plate The protein of antler plate was mainly concentrated below $29.0 \mathrm{kDa}$, and a band around $20.1 \mathrm{kDa}$ was obvious.

A total of 15 peaks were collected and labeled as $6.17 \mathrm{~min}, 6.80 \mathrm{~min}, 8.78 \mathrm{~min}, 13.8 \mathrm{~min}, 15.70 \mathrm{~min}, 18.84$ min, $20.31 \mathrm{~min}, 20.76 \mathrm{~min}, 21.91 \mathrm{~min}, 23.51 \mathrm{~min}, 28.93$ min, $30.89 \mathrm{~min}, 31.99 \mathrm{~min}$, and $32.80 \mathrm{~min}$ according to the peak time. As shown in Figure 2, the large peak between 3.2 and $4.0 \mathrm{~min}$ is the solvent peak. According to the relative abundance of the representative substance at each peak (the height of the peak is positively correlated with the relative abundance of the representative substance), the 8 peaks of $13.8 \mathrm{~min}, 15.70 \mathrm{~min}, 18.84 \mathrm{~min}, 20.31 \mathrm{~min}$, $20.76 \mathrm{~min}, 28.93 \mathrm{~min}, 30.89 \mathrm{~min}$ and $32.80 \mathrm{~min}$ were selected for further study.

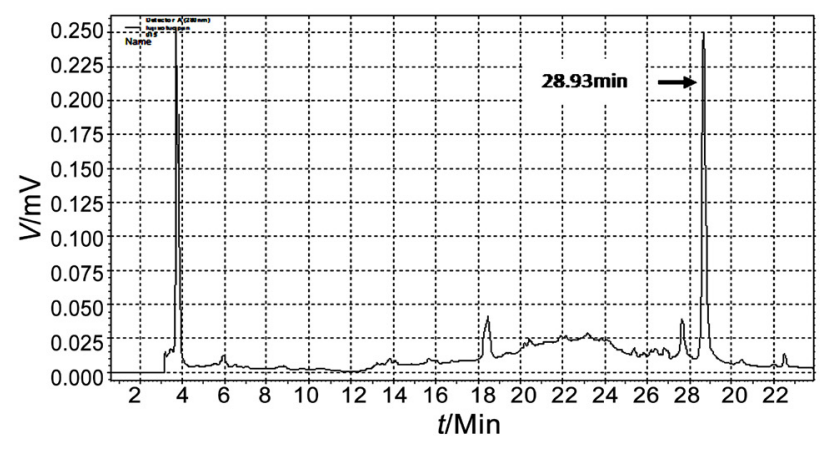

Fig. 2. The result of analytical reverse high performance liquid chromatography. A total of 15 peaks were collected. The large peak between 3.2 and $4.0 \mathrm{~min}$ is the solvent peak, and the peak appearing at $28.93 \mathrm{~min}$ has a relatively high abundance.

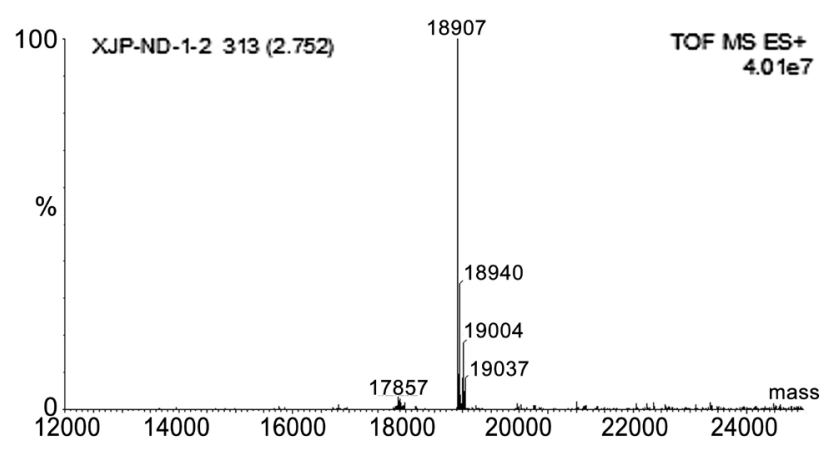

Fig. 3. Molecular mass detection of the monomeric peptide. Mass of the monomeric peptide was determined by Bruker micOTOF OllQ TOF with an experimental accuracy of $\pm 0.1 \%$, the peak is due to solvent interference. The molecular mass of this novel polypeptide was 18907Da.

Detection of electrospray mass spectrometry of analytical RP-HPLC samples

As shown in Figure 3, through the mass spectrum detection, it was found that the peak time of $28.93 \mathrm{~min}$ peak small molecule protein contained in high purity, the molecular massis $18.907 \mathrm{kDa}$. Therefore, the peak of $28.93 \mathrm{~min}$ was chosen for the target of peak, the relative molecular mass of $18.907 \mathrm{kDa}$ antler plate of small molecule protein was identified as target protein for the next phase of enrichment, and named the APP-1.

The protein purifier was used for multiple times of enrichment, and a total of $20 \mathrm{ml}$ enrichment solution was collected. The reverse HPLC diagram of the enrichment was shown in Figure 4. The concentration solution was merged and 40L was taken out fordetecting the purity of the concentration solution. 


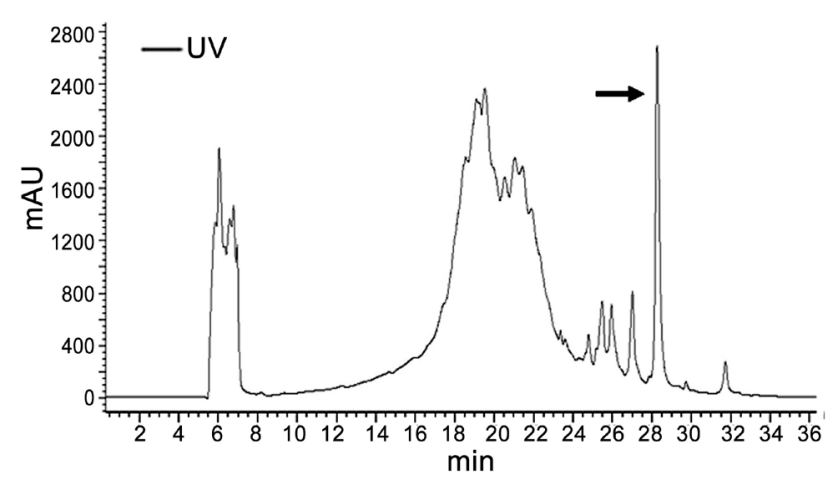

Fig. 4. Liquid enrichment of reversed phase high performance liquid Chromatography. The arrow in the figure showed the enriched target protein with a molecular weight of $18907 \mathrm{Da}$.

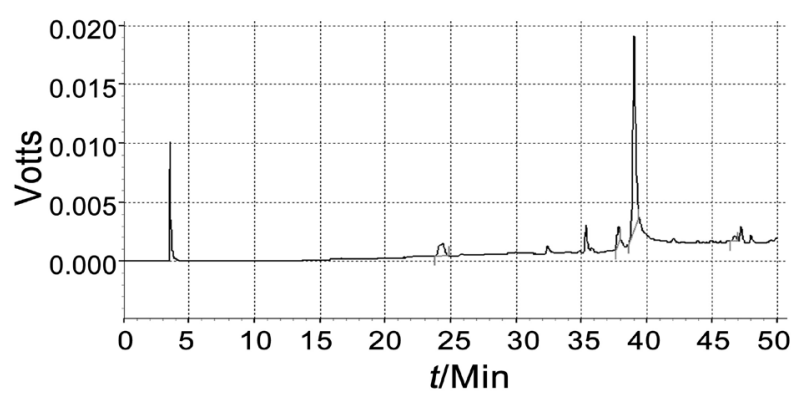

Fig. 5. Purity identification of the monomeric peptide from antler plate. Purity identification of the monomeric peptide by utilizing the HPLC, the purity of this novel polypeptide was $90 \%$.

\section{Results of HPLC purity detection of target protein enrichment solution}

In the newly set gradient, the target protein appeared at about $39.4 \mathrm{~min}$, which was in line with the expected judgment, and it could be found that the target protein was of high purity and met the sequencing requirements (the protein purity was up to $90 \%$ ).

After enzyme solution (Fig. 5), the enzyme solution segments were identified by MS/MS secondary mass spectrum identification with the application of reverse high performance liquid for enrichment of digestion fragments and tandem mass spectrometry identification technology. The amino acid sequence was AAQSLLACGAARLYKIIQQWPHYRR, the fragment was compared in the NCBI protein database by the Mascot software, It was found the matching protein is PGRP (peptidoglycan recognition protein), scored 1634, isoelectric point is 9.62 , and was on the $\mathrm{C}$-terminal.
Analysis of bacteriostatic effect of target protein

Under the effect of various bacteriostatic agents, Enterobacter aerogenes, Bacillus subtilis, Escherichia coli, Pseudomonas, Staphylococcus intermediis, xylose Staphylococcus all showed different degree of inhibitory effect, while Candida albicans, Lactobacillus grigni, bizarre Proteus and slow Staphylococcus were not inhibited. The inhibitory effect of total protein and small molecule protein monomer on gram-positive bacteria was stronger than that on gram-negative bacteria, but not on Candida albicans. The comprehensive bacteriostatic ability was from large to small as small molecule protein monomer $>$ positive control $>$ total protein group. The specific results are shown in the Table II.

Table II. The bacteriostatic ring diameter of every kind of bacteria

\begin{tabular}{llll}
\hline & Group A & Group B & Group C \\
\hline Enterobacter aerogenes & $4.87 \mathrm{~mm}$ & $5.11 \mathrm{~mm}$ & $6.13 \mathrm{~mm}$ \\
Bacillus subtilis & $4.99 \mathrm{~mm}$ & $0 \mathrm{~mm}$ & $7.01 \mathrm{~mm}$ \\
Escherichia coli & $1.51 \mathrm{~mm}$ & $1.15 \mathrm{~mm}$ & $2.02 \mathrm{~mm}$ \\
Pseudomonas & $3.62 \mathrm{~mm}$ & $2.21 \mathrm{~mm}$ & $3.77 \mathrm{~mm}$ \\
Staphylococcus intermedius & $3.88 \mathrm{~mm}$ & $2.27 \mathrm{~mm}$ & $3.94 \mathrm{~mm}$ \\
Xylose Staphylococcus & $5.77 \mathrm{~mm}$ & $3.44 \mathrm{~mm}$ & $8.93 \mathrm{~mm}$ \\
\hline
\end{tabular}

Group A, positive control; Group B, total protein; Group C, monomeric protein

\section{DISCUSSION}

Among many purification methods for protein polypeptides, high performance liquid chromatography (HPLC) has been used by more and more scholars due to its advantages of high recovery rate and good separation effect (Zhang et al., 1998; Liu et al., 2008) In this experiment, RP-HPLC was used for the separation of small and medium molecular protein monomers. RP-HPLC is widely used in the separation of non-polar substances and is also a commonly used method in the separation and purification of proteins and polypeptides (Wang et al., 2009). The setting and adjustment of gradient in RP-HPLC is the decisive factor for obtaining the pure product of the target (Czerwenka and Lindner, 2010). In this experiment, analytical liquid phase analyzer and $\mathrm{C} 18$ column were used to explore the retention time of the target protein. In order to ensure the full combination of the sample and the stationary phase, acetonitrile concentration was adjusted to zero within the first five minutes of setting the gradient. Because the target is a small molecule protein, the detection wavelength of the ultraviolet spectrophotometric detector is still $215 \mathrm{~nm}$. The target was determined to have a 
retention time of $28.93 \mathrm{~min}$ and a relative molecular weight of $18.907 \mathrm{kDa}$ by electrospray mass spectrometry and electrophoresis. The protein purification system used for enriching the target small molecule protein could increase the sample size, increase the flow rate to save time. The purity of the enriched substance was detected, it was found that the purity of the small molecule protein monomer with the relative molecular weight of $18.907 \mathrm{kda}$ reached more than $85 \%$, meeting the amino acid sequencing standard.

Edman degradation method is a chemical sequencing method (Shen and Fang, 2002), which is the process of determining amino acid residues from the n-terminal of the peptide chain. However, the current technical level limits the automatic sequencers to only measure 30 50 amino acids at most at the $\mathrm{N}$ end, and the larger the measured protein is, the more expensive it will be. Therefore, this method is not applicable to the determination of the full sequence of small molecular proteins and polypeptides with molecular weight higher than $5 \mathrm{kDa}$ (Chen et al., 2002). The sequencing method used in this experiment was mass spectrometry sequencing method, which could determine the full sequence of relatively large molecular weight proteins and polypeptides, but the premise was that the measured proteins must be known proteins. The small molecule protein monomers obtained in this experiment were enzymatic hydrolyzed by trypsin, and MS/MS secondary mass spectrometry was used to identify the enzymatic hydrolysis fragments, and the corresponding peptidoglycan recognition protein (PGRP) was found to match with the peptidoglycan recognition protein PGRP by using Mascot software in the NCBI protein database.

Peptidoglycan (PGN) is an important pathogenassociated molecular pattern (PAMP) in innate immune response, and is one of the components of bacterial cell walls, especially abundant in gram-positive bacteria (Lu et al., 2006; Zheng et al., 2010). Peptidoglycan recognition protein is an innate immune molecule found in insects, mollusks and vertebrates. Up to now, 19 peptidoglycan recognition proteins (PGRPs) have been discovered and cloned, most of which are found in insects, but only 4 in mammals. PGRPs function has the following three aspects: function recognition receptors (identify fungi or bacteria invasion and invasion signals to Toll and IMD way to produce antibacterial peptides), effect factor function (which has the function of coagulation function and amidase sterilization PGRPs direct action and kill the pathogenic microorganisms) and regulating function (adjust the phagocytosis and antimicrobial peptide synthesis) (Chen and Lv, 2014). Among the 19 existing PGRPs, the minimum value of amino acid residues content is 135 and the maximum value is $576(\mathrm{Lv}$ and Chen, 2002). The relative molecular mass of PGRPs (short peptidoglycan recognition protein) is between 18 and $20 \mathrm{kDa}$, and the number of amino acids is about 200, with signal peptide (Xu and Liu, 2014). Mammalian peptidoglycan recognition proteins are PGRP-1, PGRP -2, PGRP-3 and PGRP-4, respectively. In order to ensure the stability and activity of PGRPs, disulfide bonds exist in all four PGRPs of mammals in their PGRP structural domain (Zhang et al., 2012). Among them, PGRP-1, PGRP-3 and PGRP-4 are secreted proteins (Lu et al., 2006), which can be pasted into dimer through disulfide bond (Zhang et al., 2005), while PGRP-2 can only form dimer through disulfide bond with pgrp-2 (Xu et al., 2004). Another study found that the subject, human PGRP-1, PGRP-3, PGRP-4 and individual dimer of some gram-positive bacterium and negative bacteria (pathogenic or non-pathogenic) has the function of inhibiting or killing (Lu et al., 2006), antiseptic effect depends on the $\mathrm{N}$ side glycosylation and bivalent cation, by combining the bacterial cell wall peptidoglycan and bacteriostatic bactericidal effect of interaction of $(\mathrm{Lu}$ et al., 2006). When pathogenic microorganisms invade, the expression of PGRPs will increase significantly (Ren et al., 2014). Bacteriostatic peptides and proteins have a broad spectrum of antibacterial activity. Bacteriostatic peptides and antibacterial protein gene encoding, widely exists in insects, plants and animals and in human body, the body important immune molecules in congenital immune system, so it does not produce harmful side effects at the time of application in the human body, is more healthy than antibiotics antibacterial substances, the development and utilization has a good prospect, and scientific researchers also focus on it in recent years (Li et al., 2011, Han and Sun, 2009). At present, studies on total peptides of antler plate are mostly focused on pharmacological activities and animal experiments (Cao and Bao, 2011, Wang et al., 2015), with few reports on bacteriostasis. In addition, most of the strains used in these few antibacterial experiments were less than 4 species, which could not reflect the actual antibacterial situation of antler plate protein comprehensively and objectively. Therefore, the antibacterial activity of antlerplate protein was preliminarily studied in this study. Two kinds of protein polypeptides were obtained from the antler plate, namely, small molecule protein monomer of antler plate and total antler plate protein. The antibacterial activity of the two proteins was studied by disc diffusion method. Bacteriostatic test in vitro bacteriostatic agent is used to determine the bacteriostatic effect of detection means, Zhao et al. (2008) and Yang et al. (2016) successfully isolated new type of antibacterial peptide with relative molecular mass of 4366.91 from bullfrog skin by dextran gel chromatography (Sephadex G-50), RP-HPLC, mass spectrometry and other methods, and they studied the 
antibacterial effect of antimicrobial peptides against Staphylococcus aureus.

When studying tbacteriostatic activity of bacteriostatic peptides and bacteriostatic proteins, it is very important to select bacterial species, which should include gram-positive bacteria, gram-negative bacteria and fungi as far as possible, because the selection of a single or individual bacterium cannot objectively reflect the antibacterial situation of the antibacterial substance. A total of 10 species of bacteria were selected, including gram-negative and gram-positive bacteria, and fungus were candida albicans. All experimental bacteria must be passaged less than 5 generations. The positive control set in the experiment was ampicillin, and the concentration of bacteriostatic agent in each test group was $10 \mathrm{mg} / \mathrm{mL}$. It was found that antler plate protein monomer and antler plate can inhibited parts of gram negative bacteria and gram positive bacteria used for experiment in different degrees, but not fungus (candida albicans) used for experiment. And the inhibition effect to gram positive bacteria produce was stronger than the inhibition effect to gram-negative bacteria. However, the monomer of antler plate protein obtained by us, with molecular weight of $18.907 \mathrm{kda}$, was matched with the mammalian short-type peptidoglycan recognition protein, and the comprehensive bacteriostasis effect was better than the total protein of antlerplate, with strong bacteriostasis ability. Tang and $\mathrm{Hu}$ (2018) prepared two kinds of small peptides of antler plate by Sephadex G-50 gel chromatography and enzymatic hydrolysis method and used the filter paper diffusion method to study the antibacterial activity of two small peptides in vitro. The results showed that the two small peptides of antler plate had different inhibitory effects on Gram-negative bacteria and Gram-positive bacteria. Among them, the inhibitory effect of these two small peptides on Gram-positive bacteria is stronger than that of Antibacterial effect on Gram-negative bacteria. This result is basically consistent with the results of this study. However, its specific antibacterial mechanism still needs to be further clarified.

\section{CONCLUSIONS}

Our results indicated that a protein monomer with a molecular weight of $18.907 \mathrm{kDa}$ was isolated and purified from the antler plate. This novel and monomeric APP1 has antibacterial activities Including Gram-negative bacteria and Gram-positive bacteria, and imply that it is likely an important component of antibacterial activity in antler plate polypeptide. Our study will provide an important theoretical basis for the in-depth study of the bacteriostasis spectrum of deer antler plate protein. At the same time, the results of this study will provide new ideas for the development of new natural antibacterial proteins from traditional Chinese medicine.

\section{ACKNOWLEDGEMENT}

We acknowledge the financial supports of the National Natural Science Foundation of China under Grant No. 31572372 and No. 30972083.

\section{Ethical standards}

The experimental procedures were approved by the appropriate committee of our university.

\section{Statement of conflict of Interest}

The authors declare that they have no conflict of interest.

\section{REFERENCE}

Czerwenka, C. and Lindner, W., 2010. Detection of the adulteration of water buffalo milk and mozzarella with cow's milk by liquid chromatography-mass spectrometry analysis of $\beta$-lactoglobulin variants. Fd. Chem., 122: 901-908. https://doi.org/10.1016/j. foodchem.2010.03.034

Chen, J., Fi, H. and Chen, Y., 2002. Application of mass spectrometry on the sequencing of peptides and proteins. Chinese J. Org. Chem., 22: 81-90.

Chen, K.K. and Lv, Z.Q., 2014. Peptidoglycan recognition proteins (PGRPs) in insects. Acta Ent. Sin., 57: 969-978.

Cao, S.N. and Bao, H.Y., 2011. Research progress on chemical constituents and pharmaceutical activities of antlers. J. econ. Anim., 15: 230-233.

Huang, F.J., Ji, J.X. and Qian, J., 2010. Isolation, characterization and biological activity of anovelpeptide from sika (Cervus Nippon Temminck) antler. Pharmaceut. Biotechnol., 17: 151-156.

Huang, J.F., Wang, W. and Wang, X., 2011. Comparison of antibacterial activity of antler and deer flower protein extracts. Jilin Agric., 9: 43, 55.

Han, W.Y. and Sun, C.J., 2009. Research progress on antimicrobial peptides and its development prospect. Chinese J. Vet. Drug, 43: 11-19.

Li, S.F., Wang, F., Wang Y.F. and Zhang G.H.., 2011. Advances in antler disk research. Heilongjiang Anim. Sci. Vet. Med., 10: 34-37.

Liu, G.Y., Mao, X.J. and Chen J.Y., 2008. The fundamental principle and application of reversedphase high-performance liquid chromatography. 
NingBo Chem. Indust., 3: 22-26.

Lu, X., Wang, M. and Qi, J., 2006. Peptidoglycan recognition proteins are a new class Of human bactericidal protein. J. biol. Chem., 281: 58955907. https://doi.org/10.1074/jbc.M511631200

Lv, C.W. and Chen, Z.L., 2002. Peptidoglycan recognition protein. Immunol. J., 18: S88-S90.

Li, G.H., Hong, Z.M, and Jia, Y.J., 2011. Activities and mechanisms of action of antimicrobial peptides. Chinese J. Anim. Nutri., 23: 546-555.

Qiu, F.P., Ma, B. and Wang, Z.B., 2007. Study on the purification and activity of antler plate protein. $J$. Changchun Univ. Technol. (Nat. Sci. Ed.), 28: 144147.

Ren, F.F. and Yang, W.Y., 2014. Peptidoglycan recognition protein (PGRP) in insect innate immunity. Guangdong Canye, 48: 34-38.

Shen, Y. and Fang, W.J., 2002. Development of detection techniques of protein sequencing. Chinese $J$. Pharmaceut., 33: 514-518.

Tang, Z.J. and Hu, W., 2018. Extraction and antimicrobial activity of small peptides from sika deer antler plate. Heilongjiang Anim. Sci. Vet. Med., 07: 17-24.

Wang, Z.B., Qiu, F.P. and Xie, S.L., 2008. Studies on preparation and activity of the coronet polypeptide. J. Chinese Inst. Fd. Sci. Technol., 8: 28-32.

Wang, J., Zhang, Q.H. and Wang Z.H., 2009. Determination ofmajor bovine milk proteins by reversed-phase high performance liquid chromatography. Chin. J. Anal. Chem., 37: 1667-1670. https://doi.org/10.1016/S18722040(08)60146-2

Wang, J.N., Gao, Y.G., Ji, Q., Zhao, Y., H, Zhong, M., $\mathrm{Yu}$, L. and Zhang, L.X. 2015. Research progress on quality and effect assessment of antlers plate. Shanghai J. Trad. Chinese Med., 49: 102-105.

Xiao, Y.Q., 2012. Report of bacteriostatic test in vitro of deer Jiaopan powder. Western J. Trad. Chinese
Med., 25: 18-19.

$\mathrm{Xu}, \mathrm{X}$. and Liu, Z.Y. 2014. Study of peptidoglycan recognition proteins in innate immune system. Progr. Vet. Med., 35: 94-98.

$\mathrm{Xu}$, M., Wang, Z. and Locksley, R.M., 2004. Innate immune responses in peptidoglycan recognition protein L-deficient mice. Mol. Cell Biol., 24: 79497957. https://doi.org/10.1128/MCB.24.18.79497957.2004

Yang, X.G., Chen, Y.X., Liu, X.D., Liu, Q.Z., Pi, X.M., Liu, Y.H. and Zheng, D., 2016. De novo characterization of velvet skin transcriptome at the antlers tips of red deer (Cervus elaphus) and analysis of growth factors and their receptors related to regeneration. Pakistan J. Zool., 48: 151157.

Zhang, H., Wang, J.D. and Zhong, H.M., 1998. Studyof Protein Separation by Reversed Phase High Performance Liquid Chromatography. Chinese J. Chromatogr., 16: 220-222.

Zheng, L.P., Yu, M. and Zou, X.Y., 2010. Function of gram-negative binding proteins and peptidoglycanrecognition proteins in invertebrate innate immune response. Chinese J. Microecol., 22: 171-174.

Zhang, Z.L., Guo, Y.H. and Luo, T.C., 2012. Research progress on peptidoglycan recognition proteins of medical shells and molluscs. Chinese J. Parasitol. Parasit. Dis., 30: 312-316.

Zhang, Y., Vander Fits L. and Voerman, J. 2005. Identification of serum N-acetyl muramoyl-Lalanine amidase as liver peptidoglycan recognition protein 2. Biochim. biophys. Acta, 1752: 34-46.

Zhao, R.L., Han, W.Y., and Han, J.Y., 2008. Isolation, purification and activity of a novel antimicrobial peptide from skin of Rana catesbeiana. Chinese J. Biolog., 21: 694-697. https://doi.org/10.1016/j. bbapap.2005.07.001 